Original Research

\title{
Community stigma on the health care providers during COVID-19 Pandemic
}

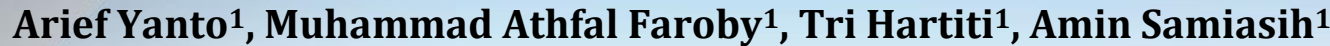

1 Universitas Muhammadiyah Semarang, Indonesia

\section{Article Info}

\section{Article History:}

Submitted: Mar 6th 2021

Accepted: June 1st 2021

Published: June 23rd 2021

\section{Keywords:}

Stigma; Health Workers;

Pandemic; Covid-19

\begin{abstract}
Stigma can be an obstacle in efforts to prevent, treat and treat COVID- 19 patients. Negative stigma can cause psychological problems for health workers during the COVID-19 pandemic. Stigma is often associated with health problems including COVID-19 which is caused by fear and lack of knowledge. This study aims to determine the image of the community's stigma against health workers during the COVID-19 pandemic. This study used a quantitative descriptive research design with a survey approach using a questionnaire filled out via google form. Sampling was done through convenience sampling. The sample of this study was 138 respondents who met the inclusion criteria. Most of the respondents did not give stigma labelling $82.6 \%$, did not give stigma stereotype $81.9 \%$, did not give stigma separation $89.9 \%$ and did not give stigma discrimination $77.5 \%$ to health workers. The results showed that the community did not give stigma of labelling, stereotype, separation and discrimination to health workers during the COVID-19 pandemic. It is hoped that this research can be used as input to prevent the emergence of a negative stigma against health workers during a pandemic.
\end{abstract}

\section{INTRODUCTION}

The coronavirus pandemic, well known as COVID-19, has been declared as a public health emergency of international concern ${ }^{1}$ and it also has spread out worldwide. The World Health Organization (WHO) has released more than $63,965,092$ confirmed cases with a death toll of $1,488,120$ cases. $^{2}$ In Indonesia the confirmed COVID-19 cases is 549,508 with 17,199 mortality cases. ${ }^{3}$ However, among all of the provinces, Semarang became the highest confirmed cases in Central Java province, Indonesia with a total of 30,217 confirmed cases. ${ }^{4}$
The increasing number of the daily confirmed cases of COVID-19 requires high demand of healthcare workers to take care the patients. ${ }^{5}$ Nurses, midwives and other health workers who dealing with the COVID-19 outbreak face new challenges including stigma and discrimination by the community $^{6}$ such as discrimination and difficulty getting the daily needs. ${ }^{7}$ Similar incidents occurred in other countries including India, the United States and Australia where the healthcare workers were threatened, beaten and expelled from their homes. ${ }^{5}$ In Indonesia at least 135 healthcare workers who experienced to be expelled from their homes because of negative stigma, 66 of them said the

Corresponding author:

Arief Yanto 
expulsion was accompanied by threats. ${ }^{8}$ The previous study defined that there were 140 COVID-19 nurses had experienced being humiliated by community. ${ }^{9}$

Stigma is a degrading distinction that is socially considered discredited, and associated with various negative stereotypes. ${ }^{10}$ It can be formed as social rejection, gossip, physical violence and denial of service.11 Stigma can be an obstacle in efforts to prevent, treat and care of the COVID-19 patient. ${ }^{12}$ The dangers of stigma can encourage people to hide the disease to avoid discrimination, prevent people from seeking immediate care and prevent them from adopting healthy behaviors. ${ }^{13}$ The Indonesian Ministry of Health revealed that the stigma and negative stereotypes given by individuals or community groups to health workers or COVID-19 patients contribute to the high death rate from the coronavirus. ${ }^{14}$ Consequently, it will only aggravate the mental health condition and disease itself. 15

Community stigma that subjected to nurses can cause psychological distress because of discrimination. ${ }^{6}$ Psychological distress and depression decreasing the immune system of health workers ${ }^{16}$ which contribute to fatal condition on the nurses health, and it affecting their nursing care delivery in hospitals.

Lack of knowledge among community and excessive fear about COVID-19 transmission is one of the risk factors for stigma to healthcare workers. ${ }^{17}$ People tend to fear with the unknown things and more easily connect fear to different community. ${ }^{18}$ Nurses and other healthcare providers working in hospital are included in the high risk group of COVID-19 exposure because they contact with COVID-19 patients directly. ${ }^{19}$

Preliminary studies showed that $40 \%$ of commuity desired that health workers should be shunned or avoided during the COVID-19 pandemic. It highlighted that many people do stigmatize to the healthcare workers during the COVID-19 pandemic. This study aims to find out how the community stigma on the health workers during the COVID-19 pandemic.

\section{METHODS}

This study applied a cross-sectional quantitative descriptive design. Measurement of community stigma carried out once to find out the description of the community stigma. The stigma indicators used in this study included: labelling, stereotype, separation and discrimination.

A total of 138 Semarang residents were recruited in this study by using random sampling from July 2020 to February 2021 with the inclusion criteria included: the participant should be a permanent resident of Semarang city with more than 1 year length of stay, have interacted with health workers during the COVID-19 pandemic, and capable to complete the google forms. The sample size of this survey was calculated by using the G Power 2.1.9.2 application, with 0.95 power and 0.05 errors.

Previously developed instruments were used to measure community stigma. The questionnaire comprised 16 statement items and it has been confirmed for the validity by using expert tests, and pilot test with a value of $r=0.381-0.815$. The reliability of the instrument also has confirmed with Cronbach's alpha of 0.894 . The questionnaire was distributed by using Google Form platform and collected directly by researchers and chief of villages.

Researchers previously have provided explanations about the purpose, benefits, and consequences to all of the respondents before data collection virtually by using the WhatsApp application video call. The involvement of respondents in this study was voluntary and without any coercion from researchers. After respondents agreed, respondents were asked to fill out 
an informed consent sheet and upload a closeup photo as evidence. Researchers have rewarded the respondents with the internet data volume. Researchers maintained the confidentiality of respondents by excluding the participants' names and identities in the research report. This research has been approved by Institutional Reviewing Board (IRB) with the following number: 746/EC/KEPKRSDK/2021.

The data was analyzed by using the SPSS application version 22. The descriptive statistics was used to analyze the data. The analysis presented an average community stigma score based on the criteria of respondents who have been measured.

\section{RESULT}

The data collection of this study was conducted in Gemah Village of Pedurungan District of Semarang City from February $8^{\text {th }}$ to $12^{\text {th }}, 2021$. A total of 138 respondents with the characteristics included: gender, age and level of education was participated. The results showed majority of the participants were female (61.9\%), graduated from with high school and undergraduate education levels and with averagely age range of age of 34.6-38.4 years old.

The average labelling scores among respondents was $75.59( \pm 12,753)$, while the non-stigmatizing score ranged from 32 to 100 . Confidence interval values (95\%) can be assumed that community scores in the population were ranged from 73.45 to77.74 years. According to the distribution of respondents' answers about stigma labelling, it showed that respondents more expressed disagree (57.3\%) with the statement of "COVID-19 is contagious if we talk or close to health workers".
Respondents' average stereotype scores were $79.51( \pm 12,974)$ with the range score of 50 to 100. Confidence interval values (95\%) can be predicted that community scores in the population was ranged from 77.13 to 81.50 years. According to participants' responses, it showed that more respondents stated disagree (52.9\%) with the statement of "Do not live at home with health workers during the COVID-19 pandemic".

The average score of participants' separations was $84.31( \pm 12,917)$ with the score ranged from 40 to 100 . Confidence interval values (95\%) can be predicted that community scores in the population were in the range of 82.14 - 86.49 years. Based on the respondents' answers, it descripted those respondents expressed more disagree (52.9\%) with the statement "Prohibiting families from associating with health workers during the COVID-19 pandemic".

Discrimination's average score among participants was $75.56( \pm 15,715)$ with score ranged from 40 to 100 . Confidence interval values (95\%) assumed the range of community scores in the population were ranged from 72.91 to 78.20 years. According to respondents' responses, it concluded that more respondents stated disagree $(56.5 \%)$ with the statement "Do not eat together with health workers in the COVID-19 pandemic". 
Tabel 1

Distribution of stigma labelling responded by the community to health care workers $(n=138)$

\begin{tabular}{|c|c|c|c|c|c|c|}
\hline Indicators & $\mathrm{f}$ & $\%$ & $\begin{array}{l}\text { Labelling } \\
\text { Stigma Score }\end{array}$ & $\begin{array}{c}\text { Stereotype } \\
\text { Stigma } \\
\text { Score } \\
\end{array}$ & $\begin{array}{c}\text { Separation } \\
\text { Stigma } \\
\text { Score } \\
\end{array}$ & $\begin{array}{c}\text { Discrimination } \\
\text { Stigma Score }\end{array}$ \\
\hline \multicolumn{7}{|l|}{ Gender } \\
\hline Male & 54 & 39,1 & 76,4 & 79,7 & 82,6 & 79 \\
\hline Female & 84 & 61,9 & 75 & 79,1 & 85,4 & 73 \\
\hline \multicolumn{7}{|l|}{ Education Level } \\
\hline Elementary school & 1 & 1 & 80 & 95 & 100 & 87 \\
\hline Junior high school & 5 & 4 & 76,8 & 86 & 93 & 83 \\
\hline Senior high school & 54 & 39 & 77,1 & 79,6 & 84,7 & 75 \\
\hline Diploma & 35 & 25 & 74,2 & 79,6 & 82,7 & 78 \\
\hline Bachelor/undergraduate & 40 & 29 & 74,3 & 77,6 & 83,5 & 73 \\
\hline Post graduate & 3 & 2 & 78,7 & 76,7 & 86,7 & 69 \\
\hline \multicolumn{7}{|l|}{ Age } \\
\hline Teenager (11-19 y/o) & 0 & 0 & 0 & 0 & 0 & 0 \\
\hline Adult $(20-60 \mathrm{y} / \mathrm{o})$ & 136 & 98,6 & 75,5 & 79,4 & 84,2 & 75,7 \\
\hline Older adult ( $>60$ tahun) & 2 & 1,4 & 83 & 75 & 90 & 63,5 \\
\hline
\end{tabular}

\section{DISCUSSION}

\section{Characteristics of Respondents}

In the gender categories, majority respondents were female (61.9\%) which supported by previous finding that female tend to be more stigmatized male. ${ }^{20}$ In contrast with the present result, prior study also highlighted that male are more do stigmatization compared to female. ${ }^{21}$ Therefore, the previous evidence showed that gender was not significantly associated with the stigmatization attitudes. Female and male have their own individual perceptions.

This study found the average age of respondents was 36.55 years old (adult). The finding is in line with prior study mentioned that younger respondents were more stigmatized compared to older adult respondents. ${ }^{20}$ This is in contrast to other prior studies that older respondents tend to be more stigmatized compared to younger/adult respondents.. ${ }^{21}$

The majority level of education of Gemah Village residents was senior high school (39.1\%). Various studies mention that there is a relationship between knowledge and the stigma that community expressed to people living with HIV/AIDS. Respondents with a higher level of education should have a better level of knowledge compared to respondents who have a low level of education.

\section{Community Stigma Labelling on the Healthcare Workers During the COVID- 19 Pandemic}

The current study found that majority of the community labelling to the healthcare workers was un-stigmatized (82.6\%). It is in line with earlier study described that most respondents did not stigmatize COVID-19 patients and health workers. ${ }^{20}$ This current finding also illustrated that lower levels of education tend to stigmatize labelling compared to higher levels of education. It is in line with previous study highlighted that people who has lower education levels (Elementary and Senior High School) have a 2.23 times greater chance of stigmatizing people (healthcare workers as the subjects of this study). ${ }^{22}$ However, this current study finding is opposite with prior study finding that described no relationship of knowledge level with the community stigma. ${ }^{23}$

Knowledge is very closely related to the participants' education. Lack of knowledge is one of the major factors causing stigma. ${ }^{24}$ Education is a process that purposed to change the people attitudes and behaviors through teaching and training. Education 
affects the learning process, the higher an education level, the easier receives information. With higher education, a person tends to get information, both from other persons and mass media. The more information that comes in, the more knowledge gained. ${ }^{25}$

\section{The Community Stereotype Stigma on the Healthcare Workers During the COVID-19 Pandemic}

The current study found majority community expressed un-stigmatized among healthcare workers (81.9\%). This is not in line with earlier study that explained majority respondents believed that health workers should have strict restrictions on their freedoms such as being isolated from their communities and families, and conversely only few respondents avoid healthcare workers and fear of being infected with COVID-19.26 Stereotypes can be formed as positive or negative views. Psychologically the development of stereotypes occurs over various human psychiatric processes in this way one chooses attention, views, compresses and categorizes other individuals is very instrumental in building stereotypes against other groups. ${ }^{27}$

Community stigma on the healthcare workers during the COVID-19 pandemic among Gemah Village was classified as a good category. It could be affected by several factors included: the individual factor that is influenced by the level of knowledge of the community itself. Moreover, this study showed that there is a significant link between knowledge of COVID-19 and stigma against health workers.. ${ }^{20}$ The proportion of people who have enough knowledge is stigmatized than people with less knowledge. Previous study suggested that stigma has a high impact on workers' performance. ${ }^{6}$ Stigmatization can affect the healthcare workers' emotional caring. Stigma to healthcare workers is psychologically stressed because of discrimination and exclusion from the community. Psychological distress and depression can decrease the immune system of healthcare workers. ${ }^{16}$ In addition, stigma and also negative stereotypes given by individuals or community to the healthcare workers or COVID-19 patients contribute to the high mortality rate due to the coronavirus infection. ${ }^{14}$

\section{The Community Separation Stigma on the Healthcare Workers During the COVID-19 Pandemic}

The study finding showed that most of participants responded un-stigmatized for the community separation sigma on the healthcare workers (89.9\%) to health workers. This is supported by the results of the distribution of respondents' answers that the majority of respondents disagree with the statement prohibiting their families from contacting with the healthcare workers during the COVID-19 pandemic. Separation can be defined as disassociation between individuals and groups because they have different social characteristics living in the same environment. ${ }^{28}$ This is opposite with prior study that explained 135 healthcare workers were expelled because of negative stigma, While 160 nurses also claimed to be shunned by surrounding people and 71 nurses felt shunned by family. ${ }^{8}$

The labelling and stereotype research found a low level of stigmatize (18.1\%). This can happen if people are still afraid of contracting the corona virus. Fear is a common cause where humans tend to fear with the unknown thing and easier to connect fear to different groups or for that matter healthcare workers. However, over time, the fear of COVID-19 decreased due to economic considerations and community boredom. ${ }^{29}$

Gemah Village Community has a relatively good level of stigma with regard to ease of access to information. It contributes that there is no longer a community that is not informed about COVID-19 including 
transmission and efforts to prevent COVID19. With social media, people can access and get information easily. News related to COVID-19 becomes information that turns trending every day at the beginning of the pandemic situation. The onslaught of news and information provided by the government through mass media makes the public accustomed to the COVID-19 pandemic. However, the lack of ability to process and filter information about COVID19 makes the establishment of negative stigma among community on the healthcare workers. ${ }^{30}$

\section{The Community Discrimination Stigma on the Healthcare Workers During the COVID-19 Pandemic}

The study found, majority the participants were not expressed their stigmatize to the healthcare workers (77.5\%). The current study result result is supported by the respondents' answer who the majority of respondents answered disagree with the statement of "prohibited to eat together with health workers in the pandemic period". This is in contrast to the prior finding that described healthcare workers who work in hospitals are discriminated against by hotel staff, they have difficulty getting food and shelter.. ${ }^{5}$

Several factors can influence the occurrence of community discrimination to the healthcare workers included: the level of knowledge about COVID-19, perceptions about health workers during the COVID-19 pandemic, education level, length of work and age. ${ }^{31}$ Furthermore, this study finding also found low percentage stigmatize rated by participants (22.5\%). Female participants were more practicing stigma than male participants, as the sam result of stigma labelling respectively. Likewise, with the respondents' education level, higher educated respondents also practicing stigma. Prior studies have been conducted showing that there is no significant relationship between knowledge and stigmatization attitudes. People tend to have various level of knowledge and different perception of an infected people by some certain diseases.

\section{CONCLUSION}

Community stigma on the healthcare workers during the COVID-19 pandemic is classified in the mild category. Majority of the participants did not practicing stigmatize to the health care workers. It is evidenced by the study findings that the indicator of stigma including labelling, stereotype, separation dan discrimination showed a good result.

\section{ACKNOWLEDGEMENT}

The researcher would like to say thank you to all the students who participated as research respondents.

\section{CONFLICTS OF INTEREST}

Neither of the authors has any conflicts of interest that would bias the findings presented here.

\section{REFERENCES}

1. Chopra KK, Arora VK. Covid-19 and social stigma: Role of scientific community. Indian J Tuberc. 2020;67:284-5.

2. Satuan Tugas Penanganan COVID-19. Tanya Jawab | Satgas Penanganan COVID-19. Satuan Tugas Penanganan COVID-19. 2020.

3. WHO. Coronavirus Disease Data Report. 2020.

4. Gugus Tugas Percepatan Penanganan Covid-19 Pemkot Semarang. Dashboard Data Covid Kota Semarang. Pemerintah Kota Semarang. 2021.

5. Singh R, Subedi M. COVID-19 and stigma: Social discrimination towards frontline healthcare providers and COVID-19 recovered patients in Nepal. Asian J Psychiatr. 2020;53:102222.

6. Ramaci T, Barattucci M, Ledda C, Rapisarda V. Social stigma during COVID-19 and its impact on HCWs outcomes. Sustain. 2020;12:1-13.

7. Poudel A. Stigma against health workers, patients and area locals continues in Covid-19 hotspots. 2020;

8. Ihsanuddin. Pemerintah Sebut 135 Tenaga Medis Diusir Karena Stigma Negatif. 2020; 
9. Humasfik. Stop Stigma pada Tenaga Medis dan Pasien Covid-19. 2020.

10. Sugiharti, Handayani RS, Lestary H, Mujiati, Susyanti AL. Stigma Dan Diskriminasi Pada Anak Dengan Hiv Aids (Adha) Di Sepuluh Kabupaten/Kota Di Indonesia. J Kesehat Reproduksi. 2019;10:153-61.

11. Dai NF. Stigma Masyarakat Terhadap Pandemi Covid-19. Stigma Masy Terhadap Pandemi Covid-19. 2020;66-73.

12. Bagcchi S. Stigma during the COVID-19 pandemic. Lancet Infect Dis. 2020;20:782.

13. Setiawati L, Sariti I, Tinggi S, Kesehatan I, Tengah J. Stigma dan perilaku masyarakat pada pasien positif covid-19. J Gawat Darurat. 2020;2:95-100.

14. Kemenkes RI. Stigma Berkontribusi Terhadap Tingginya Angka Kematian COVID-19. 2020.

15. Dinkes Bali. Mari Hentikan Stigma Negatif terkait Covid-19 - Dinas Kesehatan Provinsi Bali. 2020.

16. Rosyanti L, Usman RD, Hadi I, Syahrianti S. Kajian Teoritis Hubungan antara Depresi dengan Sistem Neuroimun. Heal Inf J Penelit. 2017;9:78-97.

17. Abudi R, Mokodompis Y, Nurfadias A. Stigma Terhadap Orang Positif Covid-19. Jambura J Heal Sci Res. 2020;2:77-84.

18. WHO. Panduan untuk mencegah dan mengatasi stigma sosial 1 terkait COVID-19. WHO. 2020. p. 1-5.

19. Pranita E. Pekerja di Rumah Sakit Rentan Terinfeksi Corona, Ahli Sarankan Ini Halaman all - Kompas.com. Kompas. Jakarta: Kompas.com; 2020.

20. Oktaviannoor $\mathrm{H}$, Herawati A, Hidayah N, Martina M, Hanafi AS. Pengetahuan dan stigma masyarakat terhadap pasien Covid-19 dan tenaga kesehatan di Kota Banjarmasin. Din Kesehat J Kebidanan Dan Keperawatan. 2020;11:98-109.

21. Hati K, Shaluhiyah Z, Suryoputro A. Stigma Masyarakat Terhadap ODHA Di Kota Kupang
Provinsi NTT. Vol. 12, Universitas Diponegoro Semarang. Diponegoro; 2017.

22. Berek PAL, Bubu W. Hubungan Antara Umur, Jenis Kelamin, Pendidikan Dan Pekerjaan Dengan Stigmatisasi Terhadap Orang Dengan Hiv/Aids Di Rsud Mgr. Gabrielmanek,Svd Atambua. J Sahabat Keperawatan. 2019;1:3643.

23. Garamina HJ. Hubungan Pengetahuan dan Sikap Masyarakat Terhadap Stigma Penyakit. J Aromed Unila. 2015;2:326-32.

24. Adhikari B, Kaehler N, Chapman RS, Raut S, Roche P. Factors Affecting Perceived Stigma in Leprosy Affected Persons in Western Nepal. PLoS Negl Trop Dis. 2014;8:2-9.

25. Budiman, Riyanto A. Kapita selekta kuesioner : pengetahuan dan sikap dalam penelitian kesehatan. Jakarta: Salemba Medika; 2014. 202 p.

26. Taylor S, Landry CA, Rachor GS, Paluszek MM, Asmundson GJG. Fear and avoidance of healthcare workers: An important, underrecognized form of stigmatization during the COVID-19 pandemic - ScienceDirect. J Anxiety Disord. 2020;75.

27. Murdianto. Stereotipe , Prasangka dan Resistensinya ( Studi Kasus pada Etnis Madura dan Tionghoa di Indonesia ). Qalamuna. 2018;10:137-60.

28. KBBI. Arti Kata Pencegahan- Kamus Besar Bahasa Indonesia. KBBI Online. 2012. p. 1.

29. Aritonang D. Ketakutan Masyarakat Makin Menurun di Tengah Lonjakan Kasus Covid-19 Kompas.id. Kompas. 2020.

30. Rahman NE, Tyas AW, Nadhilah A. Hubungan Pengetahuan Tentang Covid-19 Terhadap Sikap Stigma Masyarakat Pada Orang Yang Bersinggungan Dengan Covid-19. Share Soc Work J. 2021;10:209.

31. Paryati T, Raksanagara AS, Afriandi I, Kunci K. Faktor-faktor yang Mempengaruhi Stigma dan Diskriminasi kepada ODHA(Orang dengan HIV/AIDS) oleh petugas kesehatan: kajian literatur. Pustaka Unpad. 2013;1-11. 